\title{
Diplomasi Panda dan Hubungan Bilateral China-Jerman Tahun 2016-2019
}

\author{
Anggraini Ika Sasmita', Ario Bimo Utomo ${ }^{2}$ \\ UPN Veteran Jawa Timur ${ }^{1,2}$
}

\begin{abstract}
Since the $7^{\text {th }}$ century, China has been giving their endemic animal, Giant Panda, as one of the public diplomacy practices also known as Panda Diplomacy. Chinese Panda Diplomacy only applies to countries with historical trade and mutual links with China. This research will discuss the Chinese government's effort to implement panda diplomacy in Germany, the primary importer of high-technology products for China since 1999. As the relationship between the two countries has its ups and downs, Xi Jinping commended China's Wildlife Conservation and Association to lend a giant panda as a friendship symbol for both countries. This paper employs a qualitative method using the Eytan Gilboa framework to analyze public diplomacy application with time, purpose, public opinion, government, and instrument as the research variables. Those variables will show how panda diplomacy as a public diplomacy practices with long-term relations.
\end{abstract}

Keywords: China, Germany, Panda, Public Diplomacy

\section{ABSTRAK}

Sejak abad ke-7, China telah memberikan hewan endemik mereka, Panda Raksasa, sebagai salah satu praktik diplomasi publik yang juga dikenal sebagai Diplomasi Panda. Diplomasi Panda China hanya berlaku untuk negara-negara yang memiliki sejarah perdagangan dan hubungan timbal balik dengan China. Penelitian ini akan membahas upaya pemerintah China untuk menerapkan diplomasi panda ke Jerman, yang telah menjadi importir utama produkproduk berteknologi tinggi bagi China sejak tahun 1999. Dikarenakan hubungan kedua negara mengalami pasang surut, Xi Jinping memerintahkan Konservasi dan Asosiasi Satwa Liar China untuk meminjamkan panda raksasa sebagai symbol persahabatan bagi kedua negara. Artikel ini menggunakan metode kualitatif dengan memakai kerangka Eytan Gilboa untuk menganalisis penerapan diplomasi publik dengan variabel waktu, tujuan, opini publik, pemerintah, dan instrumen. Dari variabel-variabel tersebut, akan terlihat bagaimana diplomasi panda sebagai sebuah praktik diplomasi publik dengan hubungan jangka waktu Panjang sebagai hasilnya

Kata Kunci: Diplomasi Publik, Diplomasi Panda, China, Jerman

\section{PENDAHULUAN}

Hewan panda menjadi salah satu alat diplomasi publik China dilakukan sejak abad ke-7. Sebelum menjadi alat diplomasi publik, panda dalam sejarahnya sudah biasa diberikan sebagai hadiah kepada negara sahabat. Praktik pemberian panda pertama kali dilakukan oleh Wu Zetian pada abad ke-7 kepada Jepang sebagai simbol persahabatan (Songster, 2018). Hingga pada 1950, pemerintah China menetapkan hewan panda menjadi identitas China karena keberadaan panda yang hanya ada di China. Di Bawah kepimipinan Mao Zedong, pada tahun 1957 China kembali memberikan panda sebagai hadiah kepada mitra negara 
komunis yakni Uni Soviet (Songster, 2018). Hal ini menunjukkan adanya praktik diplomasi panda pertama kali dilakukan, sebagai simbol persahabatan dengan negara yang juga beraliran komunis (Szczudlik, 2017). Pada masa pemerintahan Deng Xiaoping tahun 1984, dibentuklah China Wildlife Conservation Association (CWCA) ditetapkan aturan baru peminjaman panda, peminjaman dengan perjanjian kontrak antara kebun binatang negara tujuan menjadi upaya konservasi dan pertukaran informasi ilmiah terkait konservasi panda. Ketentuan peminjaman antara 10 hingga 15 tahun dan juga biaya perawatan dan sewa yang dibayarkan ke China sekitar satu juta dollar (Szczudlik, 2017).

Hubungan China dengan Jerman menurut Hans Kundnani dan Jonas Parello (2012)adalah simbiosis mutualisme, dimana Jerman adalah negara dengan hampir setengah angka PDB nya bersumber dari kegiatan ekspornya. Bahkan sejak 1999 hingga akhir dekade ini, pertumbuhan ekonomi Jerman bermula dengan melakukan ekspor kepada negara-negara di Eropa hingga merambah ke penjuru Asia salah satu tujuan ekspor terbesar di Asia adalah China (Kundnani \& Parello, 2012).

Fenomena hubungan bilateral keduanya saling bergantung dari segi perdagangan ekonomi. Dari tahun 2007 hingga 2014 angka ekspor berupa kendaraan bermotor dan mesin industri menjadi angka paling tinggi ekspor ke China (Kundnani \& Parello, 2012). Angka ekspor dari tahun 2007 yang hanya 1000 Miliar Euro naik menjadi 2500 Miliar Euro pada tahun 2014. Hal tersebut mengindikasikan adanya permintaan tinggi dari China terhadap Jerman atas dua jenis produk ekspor tersebut. Permintaan China terhadap teknologi tinggi kepada Jerman pun terus naik-seiring dengan Jerman yang juga membutuhkan pasar ekspor menjanjikan yakni China (Kundnani \& Parello, 2012).

Namun, hubungan China dan Jerman tak cukup harmonis pada tahun 2016. Kondisi tersebut dapat dipahami dari adanya sikap kekecewaan Jerman kepada China yang menilai bahwa China bukan lagi sebagai mitra ekskusif bagi Jerman, melainkan adanya peningkatan persaingan dalam pengembangan industri modern (Huotari, 2015). Kekecewaan yang diungkapkan oleh Jerman adalah karena China telah membeli lebih dari empat puluh perusahaan milik Jerman dan juga menjalankan enam investasi saham pada paruh tahun 2016. Pembelian saham ini meningkat lima kali lipat dari tahun 2015. Jerman bukan lagi menganggap hubungannya dengan China sebagai "honey moon". Melainkan menganggap China sebagai kompetitor (Larres, 2016).

Pemerintah China merespon adanya ketegangan hubungan bilateral antara Jerman dan China. Pada tahun 2017, China melalui China Wildlife Conservation Association (CWCA) mengirimkan delegasi untuk menawarkan peminjaman panda sebagai bagian dari simbol hubungan baik (Schmidt, 2017). Adanya penawaran pemberian panda, mengindikasikan keinginan China ingin menjalin hubungan bilateral yang lebih erat lagi dengan Jerman. Sebagaimana praktik pemberian panda adalah suatu simbol persahabatan, penulis tertarik untuk melihat upaya diplomasi panda sebagai alat untuk melakukan diplomasi publiknya.

Dalam studi yang dilakukan oleh Elena Songster (2018:185) dalam bukunya yang berjudul Panda Nation The Construction and Conservation of China's Modern Icon menegaskan bahwa: 
"While these loans cannot be characterized as diplomatic gifts, which serve as a public display of friendship and magnanimousness, they promote diplomatic interactions and exchanges. Diplomacy enters into scientific loans at many levels, including the interaction that occurs in the basic formation and upkeep of these arrangements, as well as with the management of the funds and the training, teaching, and scientific exchanges among the scientists and animal-care staff of the participating country. The most basic form of diplomacy, of course, occurs with the simple viewing of these animals by the public in the host countries and on the internet via panda cams." (Songster,2018:185).

Keberadaan panda bukanlah suatu 'hadiah' namun lebih diproyeksikan sebagai makna simbolis, atas adanya hubungan spesial yaitu interaksi dan pertukaran baik teknologi maupun informasi dalam hal keilmuan. Keilmuan yang dimaksud adalah bagaiman interaksi antar ilmuwan dari kedua negara tersebut untuk melakukan kolaborasi terhadap konservasi panda. Menunjukkan kepada Jerman bahwa dirinya tidak kompetitif melainkan ingin bersama-sama melakukan penelitian terkait Panda. Emma Hylan (2020) melakukan analisis bagaimana peran panda terhadap hubungan bilateral China dengan Jepang menggunakan alat analisis yang dipaparkan oleh Eytan Gilboa (2008), berargumen bahwa diplomasi panda telah berhasil mengedepankan citra bangsa yang mengedepankan ikatan yang kuat dan kepercayaan yang dalam dan komitmen untuk kerjasama jangka panjang dengan negara penerima panda (Ehylan, 2020). Seperti halnya Hylan, dalam penelitian ini penulis juga akan menggunakan alat analisis yang sama dengan Hylan yaitu menggunakan kerangka diplomasi publik yang dipaparkan oleh Eytan Gilboa. Penulis ingin melihat bagaimana pelaksanaan diplomasi publik menggunakan media panda ditinjau dari kacamata diplomasi publik.

Penelitian penulis akan dimulai pada tahun 2016, batasan penelitian dibatasi hingga tahun 2019 penulis akan melihat pelaksanaan diplomasi publik China melalui panda tersebut. Limitasi penelitian juga disesuaikan dengan data yang ada serta adanya hasil dari kolaborasi konservasi panda tersebut. Sehingga dari semua latar belakang yang telah dipaparkan, rumusan masalah pada penelitian ini adalah "Bagaimana Upaya Diplomasi Publik China melalui Panda di Jerman Tahun 2016-2019? “.

\section{KERANGKA PEMIKIRAN}

Pada penelitian ini, Penulis menggunakan konsep yang akan membantu penulis untuk menjawab rumusan masalah bagaimana upaya diplomasi publik China melalui panda di Jerman. Pada penelitian ini, penulis menggunakan konsep dimensi diplomasi publik yang dipaparkan oleh Eytan Gilboa. Menurut Eytan Gilboa, Diplomasi Publik memiliki keterkaitan yang erat dengan usaha suatu negara untuk memaksimalkan kepentingan nasionalnya. Caranya adalah dengan membentuk opini masyarakat melalui pemanfaatan media dan saluran komunikasi. Persepsi masyarakat dalam memberikan opini yang baik tentunya akan menguntungkan negara tersebut, hal ini karena diplomasi publik merupakan bentuk kompleksitas hubungan antara pemerintah, media, dan opini publik (Gilboa, 2008).

Menurut Eytan Gilboa, kemunculan aktor baru dalam hubungan internasional menghadirkan konsep teoritis yang dirancang untuk menginvestigasi bagaimana aktivitas diplomasi publik dilaksanakan oleh kelompok-kelompok organisasi internasional, bahkan individu yang melewati batas negara. Kemudian, Gilboa juga memaparkan bahwa diplomasi publik memiliki karakteristik dan interaksi antara negara dan aktor non-negara melalui 
pemanfaatan soft power, komunikasi dua arah, diplomasi publik strategis, pembingkaian media, pengelolaan informasi, presentasi diri, dan gambaran atau citra diri (Gilboa, 2008).

Gambar 1. Kerangka Analisis Diplomasi Publik oleh Eytan Gilboa

\begin{tabular}{|l|l|l|l|}
\hline \multicolumn{1}{|c|}{ Jangka } & \multicolumn{1}{|c|}{ Pendek } & \multicolumn{1}{c|}{ Menengah } & \multicolumn{1}{c|}{ Panjang } \\
\hline Waktu & Jam/harian & Mingguan/bulanan & Tahunan \\
\hline Tujuan & Reaktif & Proaktif & Menjalin hubungan \\
\hline Opini publik & Manajemen berita & Komunikasi strategis & $\begin{array}{l}\text { Membangun kondisi yang } \\
\text { baik }\end{array}$ \\
\hline Pemerintah & Terhubung dekat & Terhubung sebagian & Terhubung jarak jauh \\
\hline Instrumen & $\begin{array}{l}\text { Advokasi, } \\
\text { penyiaran } \\
\text { internasional, } \\
\text { diplomasi publik } \\
\text { siber }\end{array}$ & $\begin{array}{l}\text { Hubungan masyarakat } \\
\text { berskala internasional, } \\
\text { diplomasi korporat, } \\
\text { diplomasi diaspora }\end{array}$ & $\begin{array}{l}\text { Diplomasi pertukaran, branding } \\
\text { plana }\end{array}$ \\
\hline
\end{tabular}

Sumber: Gilboa, 2009:7.

Model ini mengumpulkan variabel-variabel penting untuk menganalisis diplomasi publik seperti waktu, tujuan, media atau opini publik, pemerintah dan instrumen diplomasi publik untuk memastikan adanya diplomasi bersifat langsung, menengah atau panjang, dan berfokus pada variabel penting analisis memberikan wawasan tentang tujuan dan cara yang berbeda, perbedaan sikap terhadap media dan opini publik, tingkat yang berbeda dari asosiasi atau ikatan yang diinginkan dengan pemerintah, dan diplomasi publik yang sesuai instrumen (Gilboa, 2008).

Tingkat pertama untuk menganalisis diplomasi publik berada pada tingkat instan, penggunaan waktu hanya berlangsung dalam beberapa jam atau hanya dalam beberapa hari. Dalam tingkat ini, tujuan diplomasi publik bersifat responsif sebagai tanggapan terhadap fenomena yang lebih dahulu dilakukan oleh negara tujuan. Peran aktif pemerintah dibutuhkan berkaitan erat dengan pelaksanaan aktivitas diplomasi publik melalui upaya penyiaran internasional yang melibatkan aktivitas internet. Sehingga opini publik yang terbentuk dipengaruhi oleh pengelolaan berita dan media. Pelaksanaan pada tingkatan ini dipimpin oleh pejabat pemerintah suatu negara yang berkembang melalui media yang dikendalikan seperti: stasiun radio dan televisi negara beserta situs internet (Gilboa, 2008).

Tingkat kedua atau menengah memiliki karakteristik waktu hingga beberapa minggu maupun bulan dalam pelaksanaan diplomasi publik. Dalam tingkat menengah memungkinkan lebih banyak waktu dalam perencanaan dan implementasi kebijakan yang proaktif. Hal ini didasarkan pada teknik komunikasi strategis yang dilakukan oleh kombinasi lembaga pemerintah dan non-pemerintah selama periode yang berlangsung antara beberapa minggu dan beberapa bulan. Adapun instrumen yang digunakan melibatkan korporasi, masyarakat, dan diaspora (Gilboa, 2008). 
Tingkat terakhir dengan jangka panjang dilakukan untuk menghasilkan sikap suportif di antara publik di seluruh dunia. Inisiatif tersebut membutuhkan upaya bertahun-tahun untuk membangun rasa saling percaya dan kondisi yang menguntungkan dalam membina hubungan persahabatan dengan negara dan aktor non-negara. Organisasi yang berafiliasi dengan pemerintah maupun non pemerintah adalah aktor yang paling efektif untuk melaksanakan diplomasi publik. Instrumen diplomasi publik yang paling tepat untuk tahap ini adalah diplomasi budaya, pertukaran internasional. Dalam variabel-variabel yang telah dipaparkan oleh Gilboa tersebut, tepat untuk menganalisis bagaimana pelaksanaan diplomasi publik China melalui panda (Gilboa, 2008).

Dari pemaparan latar belakang hingga kerangka berpikir, terbentuklah sintesa pemikiran sebagai berikut. Dalam menjawab rumusan masalah bagaimana pelaksanaan diplomasi panda sebagai alat diplomasi publik China kepada Jerman tahun 2016 - 2019. Dari kerangka analisis tersebut terdapat lima variabel yaitu waktu, tujuan, media atau opini publik, peran pemerintah serta instrumen diplomasi publik yang digunakan. Dari variabel tersebut menghasilkan tiga karakteristik hubungan bilateral yang akan terjalin; immediate, intermediate, long. Pelaksanaan diplomasi publik melalui panda dapat dilihat dari bagaimana unsur-unsur kerangka diplomasi publik yang dipaparkan oleh Gilboa tersebut.

Adapun tujuan dari penelitian ini adalah untuk mengetahui upaya diplomasi publik China melalui panda di Jerman pada tahun 2016-2019. Penelitian ini adalah penelitian deskriptif dengan teknik analisis data sekunder yang bersumber dari website, media, jurnal, buku serta sumber-sumber lain dengan kredibilitas yang akurat.

\section{HASIL DAN PEMBAHASAN}

Gill dan Huang mengungkapkan sangat penting bagi China untuk menggunakan alat diplomasi publiknya untuk mempromosikan soft power nya, yaitu akan berakar pada tradisi, ideologi, budaya dan karakteristik China (Gill \& Huang, 2006). Dan selama bertahun-tahun instrumen yang digunakan untuk diplomasi publik China ini sering ditanyakan, terkait bagaimana dana sebenarnya yang efektif. Bates Gill dan Yanzhong Huang (2006) memberikan kesimpulan bahwa instrumen yang saat ini ada dan dilakukan oleh China adalah dengan menggunakan lembaga Confucius Institute, bahasa, dan pertukaran budaya. Tetapi yang dilewatkan oleh China adalah bagaimana soft power yang digunakan untuk melakukan diplomasi publiknya itu memiliki karakteristik China yang kuat, memiliki identitas China dan juga unik, yaitu adanya hewan asli China dengan nama ilmiah Ailuropoda melanoleuca atau dikenal dengan panda raksasa (Gill \& Huang, 2006).

Saat China memutuskan untuk menjadikan hewan panda sebagai identitas asli milik China, China memiliki sumber soft power yang 'unik' selain daripada sumber soft power yang tengah berjalan yakni Confucius Institute dan pertukaran bahasa maupun budaya. Keberadaan panda yang habitatnya hanya berada di China membuat China semakin percaya diri untuk menunjukkan panda di mata dunia (Xing, 2010). Pesona panda yang lucu, lembut dan penyayang ini memberikan nilai tersendiri bagi adanya 'pesan' dibalik pemberian panda oleh China (Xing, 2010). Beberapa peneliti terkait adanya fenomena panda diplomasi ini menyebutkan bahwa keberadaan panda akan membawa nilai persahabatan dan representasi sebagai negara yag damai (Hartig, 2013). 
Melalui identitas China yaitu panda, China akan mewujudkan representasi atau image nya melalui hewan ini. Menurut Buckingham (2013) bahwa tidak semua negara menerima panda, hal ini dikarenakan China memilih negara yang dipercaya sebagai mitra dan dikategorikan sebagai negara 'guanxi' atau negara yang diberikan kepercayaan oleh China untuk melakukan konservasi panda. Tidak hanya itu, negara yang menurut China berlabel 'guanxi' adalah negara yang memiliki bistorical trade yang baik dan menguntungkan bagi China (Buckingham, David, \& Jepson, 2013).

Variabel pertama yaitu waktu pelaksanaan diplomasi publik ini dijalankan. Menurut Gilboa (2008) waktu pelaksanaan terbagi atas beberapa hari, beberapa bulan dan dalam hitungan tahun. Kekecewaan Sigman Gabriel (menteri ekonomi Jerman) pada akhir tahun 2016 tersebut direspon oleh Presiden China, Xi Jinping yang memerintahkan delegasi China China Wildlife Conservation Association (CWCA) Si Ping untuk terbang langsung ke Jerman menawarkan peminjaman panda pada April tahun 2017 (Xinhua, China, Germany sign agreement on collaborative conservation and research of giant panda., 2017). Dari adanya pertemuan Si Ping dengan Andreas Knieriem (direktur kebun binatang Berlin) tersebut ditanda tangani sebuah MoU untuk menyepakati kolaborasi konservasi dan penelitian terhadap panda selama lima belas tahun dengan biaya sewa lima belas juta dollar (Schmidt, 2017). Setelah kesepakatan tersebut dilakukan, panda didatangkan ke Kebun Binatang Berlin tepat tiga hari sebelum KT'T G20 digelar di Hamburg yaitu 5 Juli 2017, Jerman. Presiden Xi Jinping secara langsung mengantarkan dua panda raksasa yakni Meng Meng dan Jiao Qing ke kebun binatang (Connolly, 2017).

Apabila melihat dari fenomena pemberian panda pada Jerman terlihat berbeda, merujuk pada penelitian yang dilakukan oleh Buckingham dalam Diplomats and Refugees: Panda Diplomacy, Soft "Cuddly" Power and The New Trajectory in Panda Conservation (2013) disebutkan bahwa masing-masing negara tujuan pemberian panda membutuhkan setidaknya bertahuntahun untuk China menawarkan pemberian panda. Dari implementasi kolaborasi peminjaman panda yang akan berlangsung selama 15 tahun, mengindikasikan adanya fenomena keharmonisan hubungan yang akan terjalin dalam jangka waktu yang lama yakni bertahun-tahun.

"I think that this event today is a symbol of the relationship between our two countries, I hope that Meng Meng and Jiao Qing can bring the two countries closer, and become the new ambassadors of the friendship between the two people." (Schmidt, 2017).

Hal tersebut disampaikan oleh Angela Merkel dalam piadato saat kedua panda datang. Jerman diwakili oleh Merkel menuturkan bahwa adanya kolaborasi penelitian panda ini sebagai simbol persahabatan antara China dan Jerman. (Connolly, 2017). Kedua panda yang datang akan membawa hubungan antara keduanya semakin erat. Meskipun tidak menutup kemungkinan bahwa selama lima belas tahun pelaksanaan diplomasi panda akan berjalan akan terdapat kejadian yang tak terduga, namun sepanjang tiga tahun berjalan, terhitung dari tahun panda datang yakni 2017 hingga tahun 2019 limitasi penelitian yang sudah berjalan tiga tahun. Hal tersebut memenuhi indikator jangka panjang dari variabel yang dipaparkan Gilboa (2008). 
Variabel kedua yakni purpose atau tujuan dilaksanakannya diplomasi panda. Sesuai dengan MoU tersebut, tentunya kegiatan yang dihasilkan adalah bagaimana interaksi yang terjalin antara para peneliti atau ilmuwan konservasi panda baik dari Jerman maupun dari China yang akan terus berkolaborasi lima belas tahun kedepan. Hubungan ilmuwan konservasi panda antara China dan Jerman rupanya membuahkan hasil yang sangat memuaskan. Hal ini dibuktikan dengan adanya sejarah baru dalam konservasi panda, dimana seekor betina panda melahirkan dua bayi panda sekaligus pada 31 Agustus 2019 (giantpandaglobal, 2019). Fenomena ini begitu langka, karena dalam sejarah konservasi panda hal itu baru pertama kali terjadi-adanya ini mengindikasikan kolaborasi yang sangat serius dijalankan oleh CWCA dan peneliti Berlin. Kedua bayi panda tersebut.

\section{Gambar 1. CWCA dengan Ilmuwan Berlin}

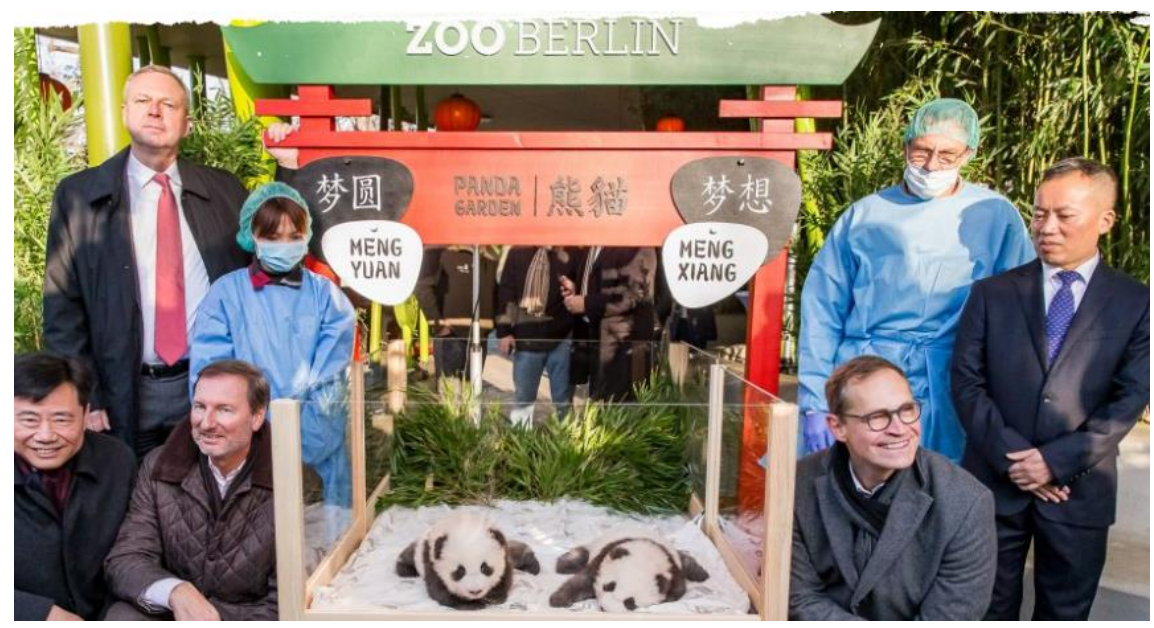

Sumber: Giantpandaglobal,2019

Pencapaian lainnya dalam menjaga hubungan bilateralnya terlihat bagaimana Wu Ken seorang Duta Besar China untuk Jerman tidak hentinya mengapresiasi dan menunjukkan ke harmonisan hubungan keduanya pada wawancara dengan Xinhua 31 Mei 2019. Dalam wawancara, Ken menuturkan kepada Xinhua:

"There are more than 70 wide-ranging and multi-level dialogue mechanisms, including government consultations, between the two countries, which will strengthen political mutual trust and further understanding and support for both sides." (Xinhua, Interview: Sino-German relations exceed bilateral ties: Chinese ambassador. , 2019)

Penulis melihat, adanya penuturan $\mathrm{Wu}$ Ken dalam kepercayaan mengindikasikan bahwa panda menjadi simbol kepercayaan dan persahabatan hingga pada 2019 keduanya melupakan kekecewaan terhadap China pada tahun 2016, image kekecewaan tersebut berhasil dibenamkan oleh China dengan image panda yang baik, lugu dan lucu-sehingga menimbulkan rasa kepercayaan kembali oleh China. Hal ini efektif untuk membangun hubungan yang lebih baik lagi dengan Jerman beberapa tahun setelah kedua panda datang. Selain itu, penuturan Wu Ken juga menjabarkan angka volume perdagangan yang dicapai keduanya pada tahun 2018 yakni mencapai 200 miliar euro (Xinhua, Interview: Sino-German relations exceed bilateral ties: Chinese ambassador. , 2019). Selain dalam segi ekonomi dan juga politik, goodwill juga secara langsung dirasakan oleh publik asing kedua negara dimana dalam penuturan Wu pula, lebih dari 60.000 pelajar China sedang belajar di Jerman dan lebih 
dari 8.000 pelajar Jerman di China. Pada 2018, sekitar 1,5 juta turis China mengunjungi Jerman, dan ada sekitar 100 penerbangan langsung antara kedua negara setiap minggunya (Xinhua, Interview: Sino-German relations exceed bilateral ties: Chinese ambassador. , 2019).

Variabel ketiga adalah bagaimana opini publik Jerman terhadap datangnya panda dan tentunya akan membawa image yang baik kepada China. Merujuk pada salah satu media Jerman, Bernhard Bartsch dari think tank Bertelsmann Foundation di Berlin mengatakan bahwa:

"The Chinese see the pandas as Chinese brand ambassadors. China obviously has an image problem in Europe and giving pandas is a very smart and easy way to win hearts" (Neo, 2017).

\section{Gambar 2. Unggahan Tweet Zoo Berlin}

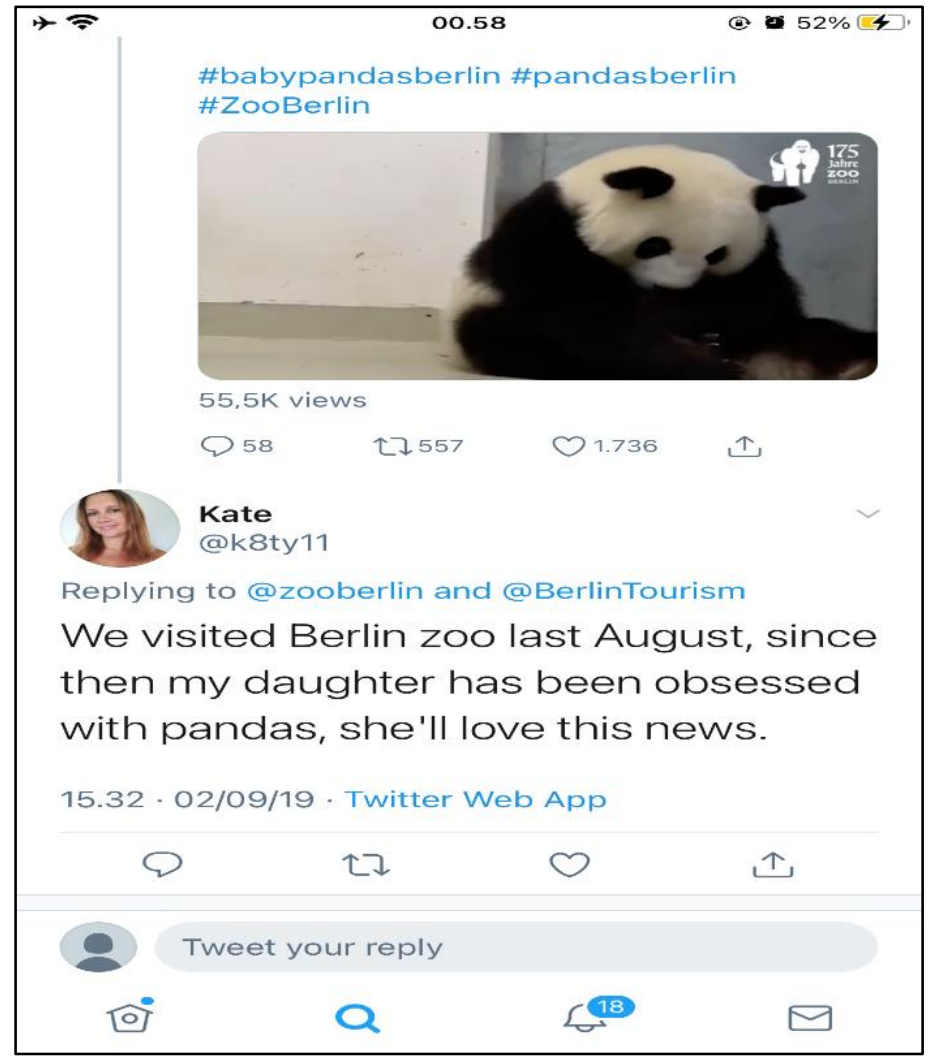

Sumber: twitter@zooberlin.09.02.2019

Dari penuturan Bernhard Bartsch menunjukkan bahwa panda berhasil mendapatkan hati publik Jerman. Selain itu, dari sosial media Zoo Berlin, selalu melakukan update kegiatan dua panda tersebut dan mendapatkan 557 retweet, 58 reply dan 1.736 likes dari publik Jerman. Selain itu, berbagai reply menunjukkan bahwa mereka terobsesi untuk melihat dan mendatangi kebun binatang Berlin untuk melihat tingkah lucu panda (Neo, 2017).

Variabel keempat adalah peran pemerintah dalam aktivitas diplomasi panda apakah pemerintah mengawasi dan turut andil dalam diplomasi panda. Menurut penulis, peran 
pemerintah dalam diplomasi panda terlihat bagaimana Xi Jinping memerintahkan untuk segera mengirimkan panda sebelum adanya pertemuan G20 di Jerman untuk memberi simbol dari Jerman bahwa keduanya adalah sahabat. Terlepas dari adanya keinginan Xi untuk mempercepat kedatangan panda, pemerintah China dan Jerman memasrahkan kegiatan kolaborasi penelitian panda kepada lembaga organisasi non pemerintah China Wildlife Conservation Association untuk melakukan kegiatan terkait konservasi panda. Variabel ini menunjukkan, meskipun peran pemerintah tidak terlalu dominan dalam mengawasi implementasi diplomasi panda, namun adanya respon Xi untuk mempercepat kedatangan panda mengindikasikan bahwa peran pemerintah juga penting dalam implementasi simbolis pemberian panda.

Variabel ke lima dalam mengkaji upaya diplomasi publik China melalui panda di Jerman adalah apakah panda termasuk instrumen diplomasi budaya-merujuk pada pemaparan Gilboa bahwa instrumen diplomasi budaya dinilai mampu membangun krakteristik hubungan bilateral jangka panjang. Diplomasi panda kepada Jerman merupakan salah satu bentuk diplomasi budaya yang menjadi fokus utama China dalam membangun soft power nya kepada publik dan pemerintah Jerman yang sempat menegang pada tahun 2016 hingga 2017 awal tahun. Panda merupakan hewan asli China yang melambangkan image kelembutan dan persahabatan negara (Xing, 2010).

Panda memiliki simbol dalam tradisi dan kebudayaan China. Dalam sejarah tradisi China, panda memiliki kekuatan dapat memerangi roh jahat sehingga kabar kelahiran Panda menjadikan kebahagiaan tersendiri bagi dinasti Tionghoa kala itu. Dari mata orang China, panda seperti pejuang karena kualitas yang mereka miliki. Panda dapat menemukan makanan untuk diri mereka sendiri, memanjat pohon, dan menahan suhu yang sangat dingin. Bahkan dikatakan bahwa panda sekuat harimau. Ini membuktikan bahwa mereka tangguh, seperti pejuang, dan China juga ingin dilihat seperti itu (Xing, 2010).

Panda raksasa melambangkan kekuatan, panda juga melambangkan perdamaian dan persahabatan karena memiliki temperamen yang lembut dan tidak suka menyerang orang lain. Selain itu, warna hitam dan putih panda dipandang sebagai representasi fisik dari Yin dan Yang, dan bagaimana keseimbangan antara keduanya membawa keharmonisan dan kedamaian. Terlebih lagi, keberadaan panda penting bagi orang China karena mereka dipandang sebagai tetangga, karena baik orang China maupun panda tinggal di China pada zaman dahulu. Hal ini menunjukkan bahwa panda dianggap sebagai bagian dari kebudayaan mereka (Xing, 2010).

\section{KESIMPULAN}

Dengan menggunakan kerangka analisis diplomasi publik oleh Eytan Gilboa, pelaksanaan diplomasi publik melalui panda pada tahun 2016 hingga 2019 cenderung mencapai karakteristik jangka panjang (long). Hal ini dikarenakan adanya pemenuhan indikator yang dipaparkan oleh Gilboa terkait karakteristik diplomasi publik. Adanya beberapa fakta yang dapat dilihat dalam variabel waktu, peminjaman panda disetujui oleh kedua negara untuk dipinjamkan selama 15 tahun-hal ini tentunya memberikan kesempatan lebih bagi China untuk selalu berkomunikasi dengan Jerman dalam penelitian bersama. Meskipun jangkauan waktu yang dipilih penulis adalah dari tahun 2016 hingga tahun 2019 
belum membidik semua pelaksanaan diplomasi panda, dimana disebutkan pada perjanjian antara CWCA dan Kebun Binatang Berlin adalah lima belas tahun, tapi dalam rentan waktu tersebut yakni sejauh tiga tahun berjalan dan melihat data terakhir yang tersedia yakni tahun 2019, maka pelaksanaan diplomasi panda dikategorikan sebagai hitungan 'years' atau tahun.

Dalam variabel tujuan, tentunya tujuan diplomasi publik ini untuk memperbaiki hubungan pasca ketegangan setahun sebelum datangnya panda dan China tentunya masih bergantung pada Jerman dalam hal teknologi tinggi manufaktur. Dari indikator karakteristik jangka panjang lainnya yaitu media dan opini publik—berbagai media dan publik Jerman antusias dengan datangnya panda, dapat memengaruhi persepsi publik Jerman. Hal ini dapat dilihat dari bagaimana media twitter Jerman yang sering mengunggah kegiatan panda, dan mendapatkan respon berupa likes dan retweets dari masyarakat Jerman.

Peran pemerintah tidak terlalu dominan, terlepas dari perintah presiden China untuk mempercepat kedatangan panda sebelum pertemuan G20. Pada variabel instrumen, tentunya instrumen yang digunakan oleh China dalam diplomasi publiknya adalah melalui panda yakni merupakan hewan asli China yang memiliki image kelembutan dan persahabatan negara. Panda raksasa melambangkan kekuatan, panda juga melambangkan perdamaian dan persahabatan karena memiliki temperamen yang lembut dan tidak suka menyerang orang lain. Selain itu, warna hitam dan putih panda dipandang sebagai representasi fisik dari Yin dan Yang, dan bagaimana keseimbangan antara keduanya membawa keharmonisan dan kedamaian.

\section{DAFTAR PUSTAKA}

Brady, M. A. (2017). Magic Weapons: China’s Political Influence Activities Under Xi Jinping. 'The corrosion of democracy under China's global influence, supported by the Taiwan Foundation for Democracy (pp. 01-57). Virginia: Arlington.

Buckingham, C. K., David, W. N., \& Jepson, P. (2013). Diplomats and Refugees: Panda Diplomacy, Soft "Cuddly" Power and the New Trajectory in Panda Conservation. Kainan Univesity, 262-270.

Cai, P. (2017). Understanding China's Belt Road Initiative. Lowy Institute, 1-26.

Campbell, M. K., \& Blackwill, D. R. (2016). Xi Jinping on the Global Stage. New York: Council Special Report No. 74.

ChinaDaily. (2013, 05 12). Beyond 'panda diplomacy'. Retrieved from China Daily: https://www.chinadaily.com.cn/china/2013-12/05/content_17137938.htm

Connolly, K. (2017). Panda fever grips Berlin on Chinese president's trip to Germany2017. Berlin: The Guardian.

Ehylan, E. (2020). Panda Diplomacy : China's Softest Power? AALBORG UNIVERSITY, AALBORG, DENMARK , 1-76.

Fischer, M. (2016). Germany gets jittery over Chinese takeovers. Retrieved 05 26, 2021, from https://www.ft.com/content/21e6eac4-0d53-3ba9-9c1d-ed3c7b851e90

giantpandaglobal. (2019). German Twins Named Meng Xiang \& Meng Yuan. Retrieved 05 21, 2021, from https://www.giantpandaglobal.com/zoo/zoo-berlin/german-twinsnamed-meng-xiang-meng-yuan/

Gilboa, E. (2008). Searching for a Theory of Public Diplomacy. The ANNALS of the American Academy of Political and Social Science, 66-77. 
Gill, B., \& Huang, Y. (2006). Sources and limits of Chinese' soft power'. Survival-Global Politics and Strategy, 17-36.

Hartig, F. (2013). Panda Diplomacy: The Cutest Part of China's Public Diplomacy. The Hague Journal of Diplomacy, 49-78.

Hooghe, d. I. (2007). The Rise of China's Public Diplomacy. The Hague: Netherlands Institute of International Relation.

Huotari, M. (2015). Germany's China policy: No honeymoon forever. European Think-tank Network on China (ETNC) , 30-36.

Johnston, M. (2014). Secondary Data Analysis: A Method of which the Time Has Come. Qualitative and Quantitative Methods in Library (QQML), 619-626.

Klotz, A., \& Prakash, D. (2008). Qualitative Methods in International Relations: A Pluralist Guide. USA: Palgrave Macmillan.

Kundnani, H., \& Parello, J. (2012). CHINA AND GERMANY: WHY THE EMERGING SPECIAL RELATIONSHIP MATTERS FOR EUROPE . European Council on Foreign Relation, 1 - 16.

Lampton, M. D. (2015). Xi Jinping and the National Security Commission : Policy Coordination and Political Power. Journal of Contemporary China, 2-15.

Larres, K. (2016, 11 16). China and Germany: The Honeymoon Is Over. Retrieved from The Diplomat: https://thediplomat.com/2016/11/china-and-gemany-the-honeymoonis-over/

Nazir, M. (1998). Metode Penelitian. Jakarta: Ghalia Indonesia.

Neo, M. H. (2017). Panda mania bits Germany as China's cuddly envoys arrive. Retrieved 05 21, 2021, from https://www.thejakartapost.com/news/2017/06/24/panda-mania-hitsgermany-as-chinas-cuddly-envoys-arrive.html

Nye, J. (2008). Public Diplomacy and Soft Power. The annals of the American academy of political and social science 616, 94-109.

Przychodniak, M. (2017). China's Plans to Strengthen Relations with Germany. PISM, 1-4.

Schmidt, A. (2017). Chinese President Xi Jinping's 'panda diplomacy' with Germany. Berlin: France24.

Shucun, Z., \& Chuntai, G. (2019). China-Germany Industrial Cooperation in the Context of The Belt Road Initiative--An Analysis Focusing on Shandong Province. Shandong Academy Social Sciences, 148-170.

Songster, E. E. (2018). Panda Nation: The Construction and Conservation of China's Modern Icon. New York : Oxford University Press.

Szczudlik, J. (2017). Role of "Panda Diplomacy" in China's Foreign Policy . PISM , 1-3.

Tiezzi, S. (2014, 04 16). China's National Security Commission Holds First Meeting. Retrieved from The Diplomat: https://thediplomat.com/2014/04/chinas-national-securitycommission-holds-first-meeting/

Wuthnow, J., \& Saunders, C. P. (2017). Chinese Military Reforms in the Age of Xi Jinping: Drivers, Challanges, and Implications. China Strategic Perspectives.

Xing, Y. (2010). CHINA'S PANDA DIPLOMACY: THE POWER OF BEING CUTE. FACULTY OF THE USC GRADUATE SCHOOL, 3-55.

Xinhua. (2014). Xi eyes more enabling international environment for China's peaceful development. Retrieved 05 08, 2021, from http://news.xinhuanet.com/english/china/201411/30/c_133822694.htm

Xinhua. (2017). China, Germany sign agreement on collaborative conservation and research of giant panda. Retrieved 12 12, 2020, from http://www.xinhuanet.com/english/201704/30/c_136246235.htm 
Xinhua. (2019). Interview: Sino-German relations exceed bilateral ties: Chinese ambassador. . Retrieved $05 \quad 21, \quad 2021$, from http://www.xinhuanet.com/english/201905/31/c_138105302.htm

Yiqin, F. (2014, 05 08). What will China's National Security Commission actually do. Retrieved from Foreign Policy: http://foreignpolicy.com/2014/05/08/what-will chinas-nationalsecurity-commission-actually-do/ 